\title{
Cases distribution of leptospirosis in City of Manaus, State of Amazonas, Brazil, 2000-2010
}

\author{
Michele Silva de Jesus ${ }^{[1]}$, Luciete Almeida Silva ${ }^{[1]}$, Kátia Maria da Silva Lima ${ }^{[1]}$ \\ and Ormezinda Celeste Cristo Fernandes ${ }^{[1]}$
}

[1]. Instituto Leônidas e Maria Deane, Fundação Oswaldo Cruz, Manaus, AM.

\section{ABSTRACT}

Introduction: Leptospirosis is an infectious disease caused by microorganisms of the genus Leptospira that affects several species of animals, including the human beings. The study described the confirmed cases of leptospirosis in Manaus, from 2000 to 2010. Methods: A descriptive study based on secondary data analysis of Secretaria Municipal de Saúde (SEMSA), Sistema de Informação de Agravos de Notificação SINAN and Sistema de Informação sobre Mortalidade (SIM) analyzing the variables: age group, gender, clinical aspects and geographic area and lethality. Results: Were reported 665 cases of leptospirosis, 339 were confirmed and $35(10.3 \%)$ died. The largest number of cases occurred in May (16.8\%), March (13.3\%) and April (11.4\%), a period of intense rainfall. The city areas with the greatest occurrence of the disease were South (26.6\%), West (23.5\%) and East (19.7\%), areas of the greatest precariousness socio-environment. The largest number of cases, including deaths, occurred in the age group from 14 to 44.9 years (74\%), being that 291 (85.8\%) were male and 48 (14.1\%) females. The most frequent symptoms were fever, myalgia, headache and jaundice. In relation to the social conditions were identified low education, poor housing, absence of sanitation and low income. Conclusions: In Manaus, despite the implementation of the Social and Environmental Program of Igarapés of Manaus (PROSAMIM), there are still areas that need a proper urbanization and improvements in socio-environmental conditions, reducing the level of exposure of the human beings that living in these locations.

Keywords: Leptospirosis. Manaus. Socio-sanitation conditions.

\section{INTRODUCTION}

Leptospirosis is an acute infectious disease that affects humans and animals caused by microorganisms belonging to the genus Leptospira. Its transmission happens in humans through the contact with urine of wild animals or domestic infected by this microorganism ${ }^{1,2}$. This disease occurs due to environmental conditions, humid and tropical climate, high temperatures, periods of heavy rain, for the presence of rodents, areas without sanitation and inadequate garbage collection ${ }^{3}$.

In developing countries as Brazil and India the leptospirosis is widespread, making it a serious public health problem, not only by the severity of its pathogenesis but as a potential element of contagion to humans. The high incidence of the disease may consider leptospirosis as a social indicator ${ }^{4}$.

Manaus presents an ecological and sanitary structure favorable to the occurrence of leptospirosis. Its climate is tropical and humid with high average temperatures above $22^{\circ} \mathrm{C}$ and abundant rain throughout the year, being most frequently in the regional winter that comprising the period from January to April ${ }^{5}$.

With the implementation of the Manaus Free Trade Zone model, from the 70's, the city had a population growth cluttered. The people flow from the State interior of Amazonas and from other brazilian regions for better job opportunities generated a series of social and sanitary problems, such as: land use intensification with the construction of houses along the igarapés, watercourse characteristic

Address to: Msc. Michele Silva de Jesus. Instituto Leônidas e Maria Deane/FIOCRUZ. Rua Teresina 476, Adrianópolis, 69057-070 Manaus, AM, Brasil.

Phone: 5592 3621-2304

e-mail: michele@amazonia.fiocruz.br

Received in 20/03/2012

Accepted in 08/10/2012 of the Amazon; and precarious housing conditions and sanitation. This problems resulting in reduced of quality of life with direct impacts on health ${ }^{6,7}$.

Although exist a vast literature about human leptospirosis in Brazil, there is a dearth of studies about this disease in Manaus, pointing to the need for support and encouragement to carry out studies about this theme.

The present study aimed to study the profile of the distribution of leptospirosis in the City of Manaus through the analysis of secondary data from 2000 to 2010, using statistical data.

\section{METHODS}

This study was conducted in the City of Manaus, capital of State of Amazonas, most populous city in Brazilian Amazon with 1,802,014 inhabitants (Instituto Brasileiro de Geografia e Estatística; IBGE, 2010). Located in the central part of the Brazilian Amazon, in Northern of Brazil, has a land area of $11,401 \mathrm{~km}^{2}$, divided into five zones and 63 districts, almost $50 \%$ of the Amazonas population resides in Manaus, being $10.9 \%$ of the population the entire brazilian northern region. Features a hydrographic net system constituted mainly for four basins, being the basins of São Raimundo and Educandos are fully inside city limits forming small streams and igarapés.

The study is based on secondary data about Leptospirosis in the City of Manaus from 2000 to 2010 obtained on the Municipal Health Secretariat (Secretaria Municipal de Saúde; SEMSA) of Manaus. Also were used data from Mortality Information System (Sistema de Informação sobre Mortalidade; SIM) and System Information of Reportable Injuries (Sistema de Informação de Agravos de Notificação; SINAN). In the period of this study were reported 665 cases of leptospirosis and 339 confirmations. 
The available data were organized into a database and analyzed using software Epi Info Version $3.3^{\circledR}$ and Statistica v. 6.0 ${ }^{\circledR}$. Variables such as age group, gender, disease clinical aspect, mortality, risk environment and geographical areas were calculated using descriptive statistics as percentages and proportions generating tables and graphs by the use of the Microsoft Office Excel $2007^{\circledR}$.

\section{RESULTS}

From 2000 to 2010 were reported in the City of Manaus 665 cases of leptospirosis, these 339 were confirmed and 35 (10.3\%) evolved for death. Analyzing the annual distribution of confirmed cases of leptospirosis was observed that there was a variation in the number of occurrence, being the largest number of cases was registered in 2009 with 63 confirmed cases (Figure 1).

With respect to the seasonality of the region, it was observed that in the months of highest concentration of rain, months of May (16.8\%), March (13.3\%) and April (11.4\%), there was an increase the number of cases of leptospirosis.

According to the Figure 2, the geographic distribution of leptospirosis in Manaus was observed in all zones of the city, with higher prevalence in southern areas (26.6\%), West (23.5\%) and East (19.7\%), in areas around watercourses polluted with higher socioenvironmental insecurity, poor housing, featuring high-risk area for transmission of leptospirosis (Figure 3).

The age group distribution of leptospirosis cases in Manaus varied from 14 to 44.9 years (74\%), being 291 (85.8\%) individuals were

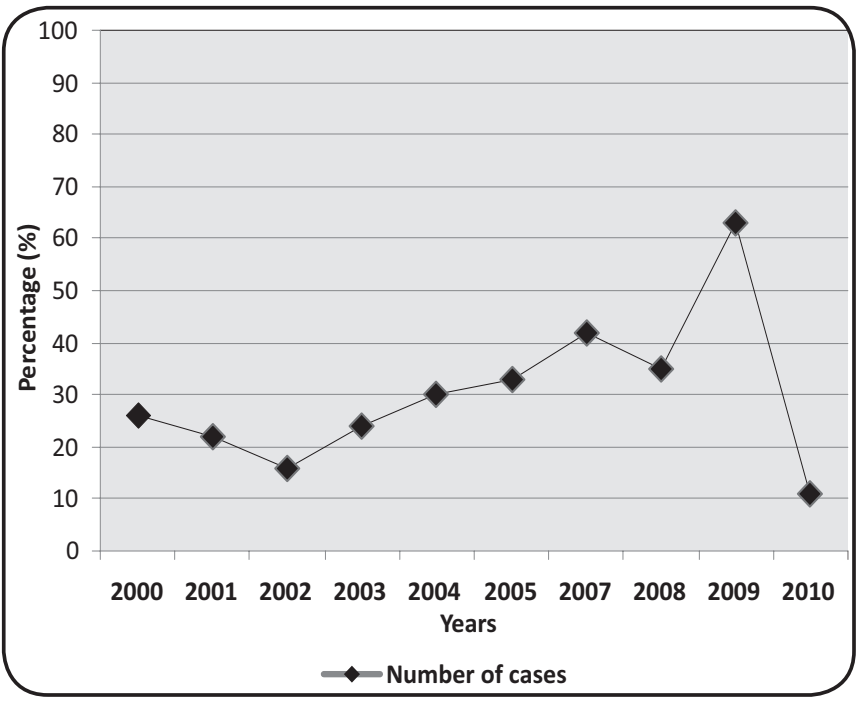

FIGURE 1 - Annual distribution of leptospirosis in the City of Manaus, State of Amazonas, Brazil, 2000-2010.

male and just 48 (14.2\%) belong to the female gender (Figure 4). In relation to the schooling rate was observed that $35.8 \%$ of patients who acquired the infection had incomplete elementary education (Table 1).

According to the data studied was found that the higher frequency of symptoms, among the people who contracted the disease, were: fever, myalgia, headache, vomiting and jaundice; that resulted in an average hospital stay of 8.5 days. Most cases of leptospirosis had a risk factor the workplace or the home itself (Table 1).

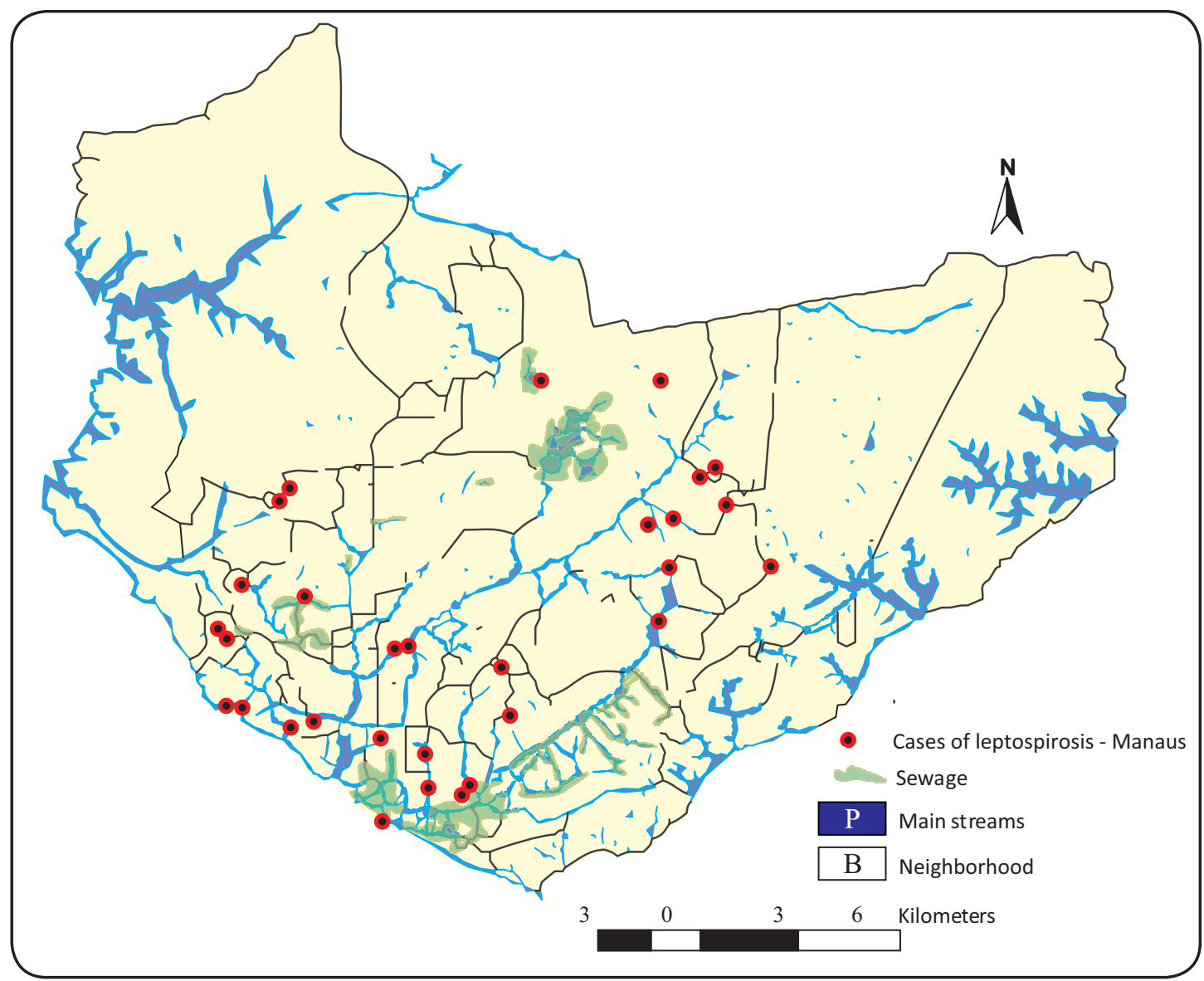

FIGURE 2 - Frequency distribution of leptospirosis cases in the City of Manaus, State of Amazonas, Brazil, 2000-2010. 


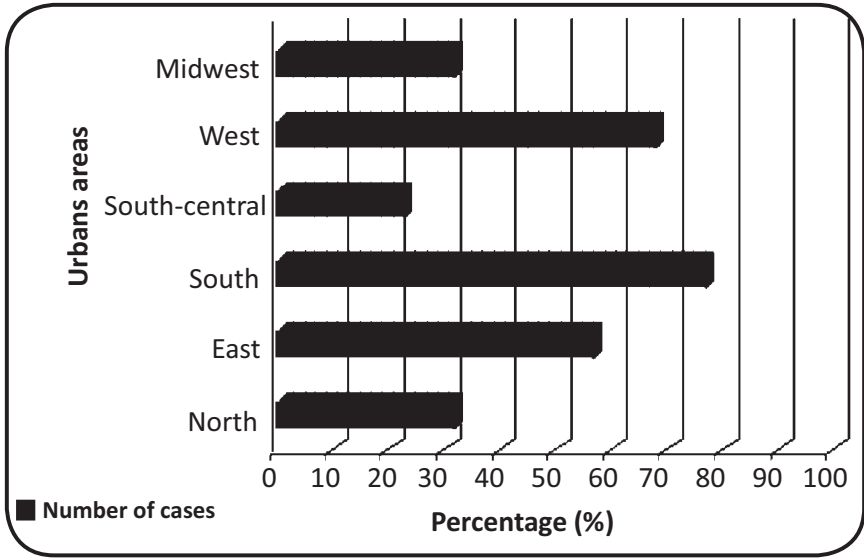

FIGURE 3 - Distribution areas of confirmed cases leptospirosis in the City of Manaus, State of Amazonas, Brazil, 2000-2010.

TABLE 1 - Clinical and epidemiological characteristics of patients with leptospirosis in the City of Manaus, State of Amazonas, Brazil, 2000-2010.

\begin{tabular}{lc}
\hline Variables & Percentage \\
\hline Symptoms & \\
fever & 98.5 \\
myalgia & 88.9 \\
headache & 87.5 \\
jaundice & 82.4 \\
vomit & 81.7 \\
diarrhea & 53.0 \\
renal complications & 29.7 \\
\hline Risk factors & \\
places with rodents & 39.5 \\
contact with rodents & 38.8 \\
floods & 35.4 \\
\hline Schooling & \\
incomplete primary school & 35.8 \\
complete primary school & 12.8 \\
high school & 9.5 \\
higher education & 2.9 \\
not reported & 57.8 \\
\hline
\end{tabular}

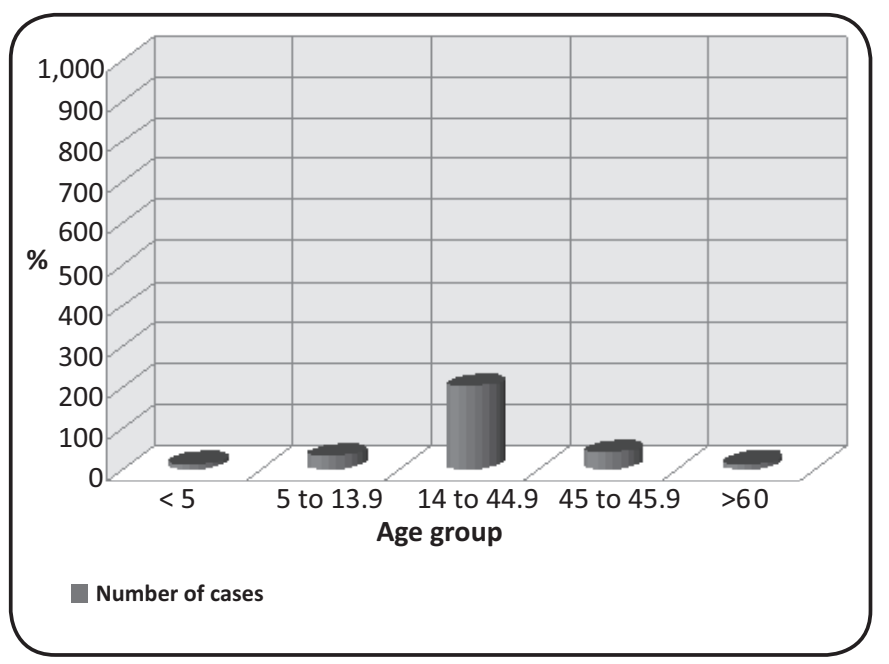

FIGURE 4 - Distribution of leptospirosis cases by age group in the City of Manaus, State of Amazonas, Brazil, 2000-2010.

\section{DISCUSSION}

According to the results of this study were confirmed leptospirosis cases in all zones of the Manaus. For Manaus be crossed naturally by igarapés or small rivers currently contaminated by waste, the disease transmission was facilitated by this route of access. In addition, it was observed also that the populations that living in areas of poor socioeconomic and sanitation situation show, proportionately, higher risk of acquiring an infection, fact also found in researches by Dias et al. ${ }^{8}$ and Romero et al. ${ }^{9}$. These authors, in their studies, associated low socioeconomic status, inadequate sanitation infrastructure, urbanization, inappropriate garbage collection, living along watercourses, untreated waste and flooding as predominant factors to increase cases of leptospirosis.

The percentage of confirmed cases in Manaus may be considered low when compared to other studies about leptospirosis in south and southeast of Brazil. These results is probably due to under-reporting of cases in which the symptoms of febrile phase form initial disease can be confused with symptoms of other diseases common in region as malaria and dengue. Although Manaus shows areas of high-risk for transmission of leptospirosis other factors should be considered for this result, such as: topography, slope of land and water outflow, mainly, in the flooding areas.

In their studies about leptospirosis, the authors as Ganoza et al. ${ }^{10}$ and Costa et al. ${ }^{11}$ pointed to the high rainfall as a factor that contributes to the increase of this zoonosis. Compared with data from Manaus, the results analyzed also showed that high levels of rain increased the number of cases of leptospirosis, which according to the Research Company of Mineral Resources (Companhia de Pesquisa de Recursos Minerais; (PRM) and other agencies responsible for rainfall monitoring, recorded in July 2009 the flood phenomenon of the system of the rivers Negro/Solimões/Amazonas that hit most cities in the state of Amazonas and especially in the City of Manaus, reaching a historic maximum height of $29.77 \mathrm{~m}^{12}$. Due to this phenomenon, which was regarded as one of the largest floods in the city, was registered in 2009 the highest number of cases of leptospirosis in the city compared to the other years studied (Figure 1).

Manaus shows seasonality characteristic of the Amazon region that in the months of greatest rainfall intensity from January to May (rainy season) was observed more frequently cases of leptospirosis in the city. Authors also characterized the leptospirosis as a disease closely linked to rainfall because the floods constitute the major risk factor for the occurrence of leptospirosis outbreaks.

According Jouglard ${ }^{13}$, the leptospirosis is characterized by various clinical manifestations could be ranging from the most severe forms such as Weil's syndrome (Triad of jaundice, renal failure, and hemorrhaging) until the milder form characterized by high fever, myalgia, vomiting, headache and diarrhea. In relation to the clinical aspects of the study in Manaus, it was observed that there was a greater initial manifestation of the disease form as shown in Table 1.

These initial signs of this disease such as fever, headache and myalgia are common symptoms in various diseases classified as acute febrile diseases. In addition, if will not properly diagnosed the leptospirosis could be under-reported and be treated as a common cold or another illness, and later evolve for the most severe form of 
the disease (renal failure and hemorrhage) and consequently taking the pacient to death ${ }^{14,15}$.

In the present study, we found that the leptospirosis is common in males aged 14 to 44.9 years, which is consistent with other research conducted by Maciel et al. ${ }^{16}$ that also identified the population most young, male, as the most infected by the disease. Probably, this fact is due to the activities of this population are linked with unhealthy activities such as cleaning sewers and lands.

According Almeida et al. ${ }^{17}$ and Ko et al. ${ }^{18}$, the leptospirosis it is identified in Brazil as an occupational disease associated to the poor socio-economic conditions of the population.

In conclusion, although Manaus shows the ecological/environmental characteristics conducive to proliferation of leptospirosis, the official data (SINAN) about the disease indicates a low prevalence pointing to under-reporting cases, being that some disease symptoms can.

Considering the surveillance importance for the control of leptospirosis, a factor to be considered it is the need of implementation of the laboratory diagnosis in the samecity, contributing for the knowledge of the true magnitude of the disease in the city, as well as a establishment of protocols of case investigation and intervention actions that are improved from the knowledge of the socioenvironmental conditions of the site contamination.

Despite the implementation of the Social and Environmental Program of Igarapés of Manaus (Programa Social e Ambiental dos Igarapés de Manaus; PROSAMIM), there are still areas that need a proper urbanization and improvements in socio-environmental conditions, reducing the level of exposure of the human beings that living in these locations.

\section{ACKNOWLEDGMENTS}

The authors wish to thank the Isaque dos Santos Sousa, Soraya Moresi Soares Vieira, Thiago Marinho Pereira and the Secretaria Municipal de Saúde (SEMSA) of Manaus.

\section{CONFLICT OF INTEREST}

The authors declare that there is no conflict of interest.

\section{FINANCIAL SUPPORT}

Fundação de Amparo à Pesquisa do Estado do Amazonas (FAPEAM). Manaus, AM, Ministério da Saúde and Conselho Nacional de Desenvolvimento Científico e Tecnológico (CNPq)

\section{ABSTRACT IN PORTUGUESE}

\section{Distribuição de casos de leptospirose no Município de Manaus, Estado do Amazonas, Brasil, 2000-2010}

Introdução: A leptospirose é uma doença infecciosa causada por microrganismos do gênero Leptospira, que acomete várias espécies de animais, inclusive o homem. 0 estudo descreveu os casos confirmados de leptospirose no município de Manaus, no período de 2000 a 2010. Métodos: Estudo descritivo baseado na análise de dados secundários da Secretaria Municipal de Saúde (SEMSA), Sistema de Informação de Agravos de Notificação (SINAN) e Sistema de Informação sobre Mortalidade (SIM) das variáveis: faixa etária, sexo, aspectos clínicos eárea geográfica e letalidade. Resultados: Foram notificados 665 casos de leptospirose, 339 foram confirmados e 35 (10,3\%) evoluíram para óbito. 0 maior número de casos ocorreu nos meses de maio (16,8\%), março (13,3\%) e abril (11,4 $\%)$, período de intensas chuvas. As zonas da cidade de maior ocorrência da doença foram a sul $(26,6 \%)$, oeste $(23,5 \%)$ e leste $(19,7 \%)$, áreas de maior precariedade socioambiental. 0 maior número de casos, inclusive com óbitos, ocorreu na faixa etária de 14 a 44,9 anos (74\%), sendo que 291 (85,8\%) pertenciam ao sexo masculino e $48(14,1 \%)$ ao feminino. Os sintomas mais frequentes foram: febre, mialgia, cefaleia e icterícia. Em relação às condições sociais, identificou-se baixa escolaridade, moradia precária, falta de saneamento e baixa renda. Conclusões: Em Manaus, apesar da implantação do Programa Social e Ambiental dos Igarapés de Manaus (PROSAMIM) ainda existem áreas que necessitam de uma urbanização adequada e melhorias nas condições socioambientais, diminuindo o nível de exposição dos indivíduos que residem nestes locais.

Palavras-chaves: Leptospirose. Manaus. Condições sociossanitárias.

\section{REFERENCES}

1. Figueiredo CM, Mourão AC, Oliveira MAA, Alves WR, Ooteman MC, Chamone CB, et al. Leptospirose humana no município de Belo Horizonte, Minas Gerais, Brasil: uma abordagem geográfica. Rev Soc Bras Med Trop 2001; 34:331-334.

2. Adler B, Moctezuma AP. Leptospira and leptospirosis. Vet Microbiol 2010; 140:287-296.

3. Mcbride AJA, Athanazio DA, Reis MG, Ko Al. Leptospirosis. Curr Opin Infect Dis 2005; 18:376-386.

4. Soares TSM, Latorre MRDO, Laporta GZ, Buzzar MR. Análise espacial e sazonal da leptospirose no município de São Paulo, SP, 1998 a 2006. Rev Saude Publica 2010; 44:283-291.

5. Toledo LM. Espaço e doença: um olhar sobre o Amazonas, Rio de Janeiro: Ed. Fundação Oswaldo Cruz; 1998.

6. Homem VSF, Heinemann MB, Moraes ZM, Vasconcellos SA, Ferreira F, Ferreira Neto JS. Estudo epidemiológico da leptospirose bovina e humana na Amazônia Oriental Brasileira. Rev Soc Bras Med Trop 2001; 34:173-180.

7. Velloso R, Relatório urbano ambiental integrado. Manaus - Projeto Geocidades. Ministério do Meio Ambiente. 2002; p. 188.

8. Dias J.P, Teixeira MG, Costa MCN, Mendes CMC, Guimarães P, Reis MG, et al. Factors associated with Leptospira sp. infection in a large urban center in northeastern Brazil. Rev Soc Bras Med Trop 2007; 40:499-504.

9. Romero EC, Bernardo CCM, Yasuda PH. Human leptospirosis: a twenty-nine-year serological study in São Paulo, Brazil. Rev Inst Med Trop São Paulo 2003; 5:245-248.

10. Ganoza CA, Matthias MA, Collins-Richards D, Brouwer KC, Cunningham CB, Segura ER, et al. Determining Risk for Severe Leptospirosis by Molecular Analysis of Environmental Surface Waters for Pathogenic Leptospira. PLoS Med 2006; 3:1329-1340.

11. Costa E, Costa YA, Lopes AA, Sacramento E, Bina JC. Formas graves de leptospirose: aspectos clínicos, demográficos e ambientais. Rev Soc Bras Med Trop 2001; 34:261-267.

12. Companhia de Pesquisa de Recursos Minerais (CPRM); Diretoria de Hidrologia e Gestão Territorial (DHT); Departamento de Hidrologia (DEHID). Relatório da Cheia 2009. Brasília: CPRM; 2009.

13. Jouglard SDD. Diagnóstico de Leptospirose por PCR e caracterização de isolados de Leptospira spp. Por sequenciamento do 16S rDNA e análise de VNTR [Thesis]. [Rio Grande do Sul]: Universidade Federal de Pelotas; 2005. 71 p.

14. Librati DH, Myint KSA, Murray CK, Gibbons RV, Mammen PM, Endy TP, et al. A comparative study of leptospirosis and dengue in Thai children. PLoS Negl Trop Dis 2007; 1:1-7.

15. Guidugli F, Castro AA, Atallah AN. Systematic Reviews on Leptospirosis. Rev Inst Med Trop São Paulo 2000; 42:47-49.

16. Maciel EAP, Carvalho ALF, Nascimento SF, Matos RB, Gouveia EL, Reis MG, et al. Household transmission of leptospira infection in urban slum communities. PLoS Negl Trop Dis 2008; 2:1-7.

17. Almeida LP, Martins LFS, Brod CS, Germano PML. Levantamento soroepidemiológico de Leptospirose em trabalhadores do serviço de saneamento ambiental em localidade urbana da região sul do Brasil. Rev Saude Publica 1994; 28:76-81.

18. Ko Al, Reis MG, Dourado CMR, Johnson, WDJ, Riley LW. Urban epidemic of severe leptospirosis in Brazil. The Lancet 1999; 354:820-825. 